\title{
Sustainable development of education: a home bank of management decisions of the university in ensuring the minimum requirements of legislation
}

\author{
Natalya Mikhaylova*, and Sergey Verkhoturov \\ Trans-Baikal Institute of Railway Transport, a branch of Irkutsk State Transport University, \\ Magistral'naya Str., 11, 672040 Chita, Russia
}

\begin{abstract}
The article discusses the issues of building a university management model focused on meeting the minimum accreditation requirements and legislative requirements in the field of higher education, ensuring the sustainable development of education. In the context of global informatization of the society, the information technologies are being introduced into the various fields of activity. The university management system did not stand aside. The authors propose the use of gamification technology through the automated tools that provide processing and analysis of big data, diagnostics of the quality of downloaded information. Gamification allows the target users to complete the assigned tasks subject to the certain rules and restrictions, which makes the process of performing them similar to a game. It simultaneously contributes to the development of the personnel, the creation of a process of rivalry, motivation and social interaction. Gamification allows the head of an educational organization to build a balanced model of organizational behavior, taking into account the model of behavior of the performers, to ensure the division of administrative and academic spheres of management. These aspects are important elements in the system of the sustainable development of education.
\end{abstract}

\section{Introduction}

In the Russian practice of managing the higher educational institutions, there is no universal system of the effective management that allows the university to be competitive and meet the requirements of the legislation for the education system. Each university independently builds a management model that integrates the properties of a value-oriented and goaloriented system.

In the context of modernization of the procedures for state regulation of the educational activities, the university acts as a learning and self-developing organization that performs educational, research, economic, socio-economic, political, spiritual, moral, and sociocultural functions. The modernization of the processes of the education system of higher

\footnotetext{
* Corresponding author: mins.80@mail.ru
} 
education, along with the development of education and research processes, make the issue of university management significant.

Citing the works of B.R. Clarke: "This is an alarming era for the universities around the world, with no end in sight. As they faced more and more difficulties in the last quarter of the twentieth century, higher education lost all the stability it probably once possessed. Since the demand is unlikely to ever decline, a return to a steady state is impossible" [1].

Analyzing the research on management systems of universities, one can come to the conclusion as follows:

- the development of the universities is greatly influenced by the state policy in the field of education, which contributes to the achievement of the goals and objectives of national and global importance [2,3];

- in the management system of the universities, a "rigid" systemic approach of management prevails, which leads to a decrease in the level of trust and an increase in administrative functions;

- centralization of management is accompanied by the deepening of the university autonomy, the formation of a corporate culture, the desire for change and excellence [3];

- the university management system is aimed at suppressing and preventing the violations of legislation in the educational sphere.

Systematic risk management in the activities of an educational organization minimizes the impact of the potential threats and the negative consequences of the factors influencing the university management process, including those related to the human factors. A wellstructured management system allows you to move to the sustainable development of the educational process.

\section{Materials and Methods}

The head of the university strives to ensure that the activities of the educational organization are effective and successful, and that the subordinate team has initiative, is responsible, and easily takes on the tasks set. Success in managing an organization is not always achieved, especially in the conditions of limited material resources. Building a management model is more related to the norms of a group behavior. With regard to the educational organization, one can consider the models of organizational behavior proposed by D. Newstrom and K. Davis (Table 1).

Table 1. Organizational behavior patterns [4]

\begin{tabular}{|l|c|c|c|c|}
\hline \multirow{2}{*}{ Model characteristics } & \multicolumn{4}{|c|}{ Organizational behavior patterns } \\
\cline { 2 - 5 } The model is based on & authoritarian & guardianship & supporting & collegial \\
\hline Management focus on & credentials & distribution & support & teamwork \\
\hline $\begin{array}{l}\text { Orientation of the } \\
\text { academic staff }\end{array}$ & subordination & $\begin{array}{c}\text { safety and } \\
\text { benefits }\end{array}$ & $\begin{array}{c}\text { solving the } \\
\text { specific } \\
\text { problems }\end{array}$ & $\begin{array}{c}\text { responsible } \\
\text { behavior }\end{array}$ \\
\hline $\begin{array}{l}\text { Psychological result } \\
\text { for the academic staff }\end{array}$ & $\begin{array}{c}\text { dependence } \\
\text { on the } \\
\text { immediate } \\
\text { supervisor }\end{array}$ & $\begin{array}{c}\text { dependence } \\
\text { on an } \\
\text { organization }\end{array}$ & $\begin{array}{c}\text { participation in } \\
\text { management, } \\
\text { decision-making }\end{array}$ & $\begin{array}{c}\text { self- } \\
\text { discipline }\end{array}$ \\
\hline $\begin{array}{l}\text { Meeting the needs of } \\
\text { the academic staff }\end{array}$ & in existence & in safety & $\begin{array}{c}\text { in the status of } \\
\text { confessions }\end{array}$ & $\begin{array}{c}\text { in self- } \\
\text { realization }\end{array}$ \\
\hline
\end{tabular}

The organization of the execution of decisions made underestimates the main place in the management of the university's activities. Whatever model of organizational behavior the 
leader uses, the model of behavior of the performers will influence the effectiveness of the decisions made. Moreover, all performers can be divided into four groups:

The first group are productive, dedicated and disciplined performers. As a rule, these employees timely and efficiently perform their work, do not conflict with the interests of the organization.

The second group is the opportunists. This group occupies the largest share of the staff, since this position is very profitable to be occupied. The work is carried out under the motto: "Tell me how to do it, I will do it." Such employees follow the decisions made by the management, but do not share the management's point of view.

The third group is the originals. Individuals who adhere to their point of view on any issue. They are characterized by the rationale of their own gain.

The fourth group is the rebels. This group includes people who do not accept the decisions of the management and are trying to come into opposition.

The level of the development of the personnel can be a reason for assigning it to a particular group. According to the theory of Hersey-Blanchard [5], an employee is ready to perform the tasks if: he is able to perform it; wants to fulfill it; is confident in his abilities.

According to this model, there are four leadership styles and four degrees of development of the subordinate (Table 2).

Table 2. Employee development levels

\begin{tabular}{|l|l|}
\hline \multicolumn{1}{|c|}{ Developmental level } & \multicolumn{1}{c|}{ Level characteristic } \\
\hline $\begin{array}{l}\text { P1 - "Not capable, but } \\
\text { ready" }\end{array}$ & $\begin{array}{l}\text { Professionalism: only basic knowledge. } \\
\text { Motivation: high, a lot of enthusiasm }\end{array}$ \\
\hline $\begin{array}{l}\text { P2 - "Not capable and not } \\
\text { ready" }\end{array}$ & $\begin{array}{l}\text { Professionalism: there is knowledge and skills. } \\
\text { Motivation: low motivated / demotivated }\end{array}$ \\
\hline $\begin{array}{l}\text { P3 - "Capable, but not } \\
\text { tuned" }\end{array}$ & $\begin{array}{l}\text { Professionalism: there is knowledge and well-developed skills } \\
\text { to complete the task. } \\
\text { Motivation: self-confidence is unstable, which can affect the } \\
\text { motivation }\end{array}$ \\
\hline P4 - "Capable and ready" & $\begin{array}{l}\text { Professionalism: mastery of skills. } \\
\text { Motivation: motivated and confident }\end{array}$ \\
\hline
\end{tabular}

The two main criteria are the professionalism and motivation, on the basis of which an employee can be attributed to a particular level of development in relation to the task [6]. It is precisely about the development of the employees in relation to the task. One and the same person can be at different stages of the development in relation to different tasks. Accordingly, the management style is situational:

- S1 - Directive style, or leadership by the orders. The leader gives the specific instructions and monitors the assignments. The main way of the management is rigid goal setting and orders;

- S2 - Mentoring style, or leadership by selling the ideas - a combination of high task and people orientation. The leader gives the instructions and monitors the implementation of the tasks, but at the same time explains the decisions made to the subordinate, invites them to express their ideas and proposals;

- S3 - Supportive style, or leadership through participation in the organization of the work process - high focus on people and low focus on the task. The leader supports and helps his subordinates in their work. The leader participates in the decision-making process, but decisions are made to a greater extent by the subordinates;

- S4 - Delegating style, or leadership by delegation. The leader transfers the authority, rights and responsibilities to other team members.

Each level of employee development in relation to the task has its own management style (Table 3), which influences the choice of the management structure. 
Table 3. Choosing the optimal management style

\begin{tabular}{|c|c|c|}
\hline $\begin{array}{c}\text { Developmental } \\
\text { level }\end{array}$ & $\begin{array}{c}\text { Management } \\
\text { style }\end{array}$ & Recommendations \\
\hline P1 & S2 & $\begin{array}{l}\text { For an employee of the P1 level ("Not capable, but ready") it } \\
\text { is necessary to clearly set the task and give the instructions. } \\
\text { The employee shall be controlled }\end{array}$ \\
\hline $\mathrm{P} 2$ & S2 & $\begin{array}{l}\text { An employee of the P2 level ("Not capable and not ready") } \\
\text { needs both directives and the support of a leader, so a } \\
\text { mentoring style is optimal. As a result of mentoring, the } \\
\text { professionalism of the employee increases }\end{array}$ \\
\hline P3 & S3 & $\begin{array}{l}\text { An employee of P3 level is capable of solving the problem, but } \\
\text { is not ready. He is good both in knowledge and skills, the } \\
\text { problem is only with the motivation and self-confidence. } \\
\text { Accordingly, the leader chooses a supportive style so that the } \\
\text { employee realizes that he is allowed to be independent - his } \\
\text { ideas find a response and are converted into work success. }\end{array}$ \\
\hline P3 & S3 & $\begin{array}{l}\text { A motivated, experienced and problem-solving employee at P4 } \\
\text { level ("Capable and ready") can lead and apply the } \\
\text { developmental leadership styles to less experienced employees }\end{array}$ \\
\hline
\end{tabular}

Two approaches are distinguished in the management structure of the universities: bureaucratic and academic ones (Table 4).

Table 4. Components of the university management structure.

\begin{tabular}{|c|c|}
\hline $\begin{array}{l}\text { The academic management structure is } \\
\text { supported by a professional team of the } \\
\text { academic staff }\end{array}$ & $\begin{array}{c}\text { Bureaucratic governance structure supported } \\
\text { by the administration and external } \\
\text { stakeholders: supervisory board, responsible } \\
\text { ministry, investors }\end{array}$ \\
\hline power of examination & control hierarchy \\
\hline \multirow{2}{*}{$\begin{array}{l}\text { decentralization and commitment to the } \\
\text { values of the professional group }\end{array}$} & division of labor \\
\hline & $\begin{array}{l}\text { standardization and formalization of the } \\
\text { processes }\end{array}$ \\
\hline
\end{tabular}

The main challenge in university management is to strike a balance between these two approaches. However, the principles of the "direct democracy" or the "vertical of power" do not work here. The task can be solved by mixing different management models, which should take into account both the division of labor and the standardization and the presence of a strong and autonomous professional group. The mode of "participation in university management" is a tool for achieving such a balance [7].

The interaction between the leader and the subordinate can be effective only with a harmonious combination of the model of behavior of the leader and the performer, implemented through a built management system, which is based on the coordination of actions aimed at solving the assigned tasks.

\section{Results and Discussion}

To fulfill the above conditions, it is proposed to apply a gamification model of management, which allows influencing the behavior of performers and applying various management styles.

For the first time, the American programmer and inventor Nick Pelling used the term "gamification" in his work. In 2003, Pelling founded a consulting firm to create game interfaces for electronic devices [8]. After that, the term began to be actively used in various fields only in 2010. 
Today, the concept of turning life into a game has spread in many areas of human life: economic, educational, political and social spheres of society [9]. The technology is used to indicate a special way of solving various problems of varying degrees of complexity.

The traditional definition of gamification is the process of applying the game mechanics to non-game activities in order to control the motivation and behavior of groups of people.

The construction of a gamification model must meet certain requirements. Based on the recommendations suggested by Queen Werbach, let's look at the main steps to create a successful gamification [10]. For this purpose, the authors recommend using a six-step model (6D) (Fig. 1).
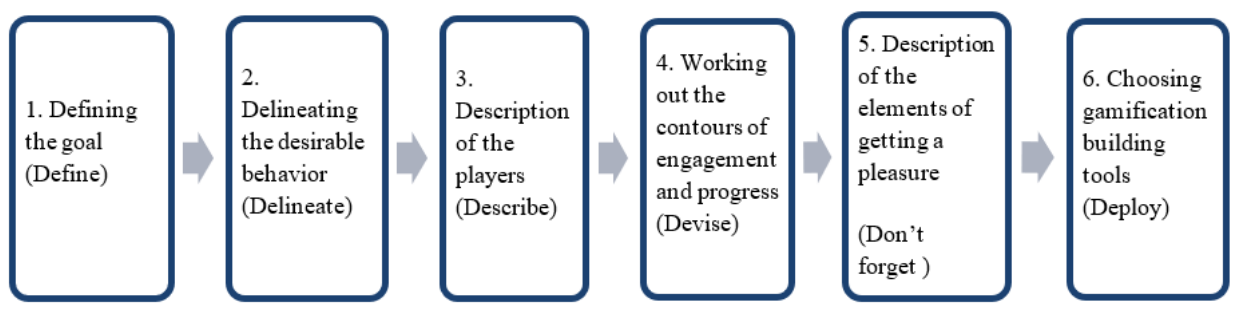

Fig. 1. Steps for introducing the gamification

Step 1. Determining the goals of gamification. The introduction of game rules into any activity is aimed at instant feedback, increasing involvement in the process, increasing the internal motivation of the desired behavior of the participants in the process while solving the strategic tasks of the organization.

Step 2. Outline of desirable behavior. In this step, intentions and secondary benefits are identified, and reasons are given as to why the existing behaviors are not satisfactory. There are many theories that describe what drives the human behavior. In order to influence the human behavior, it is recommended to use a model of the human behavior.

Consider the model of Professor BJ Fogg, director of the Motivational Technology Laboratory at Stanford University, as it relatively simply describes the motives of a person's behavior. Fogg argues that three elements are required to initiate any action:

- the user must have the sufficient motivation;

- he must be able to complete the requested action;

- you need a trigger (impulse) that activates it.

If any of the elements is absent or insufficiently expressed, the participant of the process will not cross the starting line and the action will not be performed [11].

Step 3. Description of the players. The desired behavior depends more on the types of the employees. The most interesting description of the types of the employees is given in the book "The Navigator's Handbook - 101 Leadership Lessons for Work and Life". David A. O'Brien distinguishes four types of the employees:

"Critics" easily find many reasons why the changes will not be implemented and useful. This is often due to bad previous change experiences. It is important to note that critics' negative attitude towards the changes have an impact on the rest of the organization, pushing others to refuse to change.

"Victim" tends to become isolated and not respond to challenges, since he is unable to see himself and the organization in the process of changes and after them. They want everything to remain unchanged and not be affected by the changes. Positioning yourself as a victim contributes to the fact that people turn away from you, avoid interaction.

"Outside observer" is a person who does not want to get involved in the changes. Their caution means that they wait for others to make a decision, take the initiative and responsibility as they move towards the changes. Thus, they seek to reduce the risks and get involved when they understand that it is safe. As observers try to distance themselves from changes, the rest of the staff ignore them. 
Change "guides/navigators" are the employees who positively influence the changes. They contribute to the fact that other employees of the organization change their attitude to the events taking place in the company [12].

Based on the structure of the types of the players, a system of actions is thought out, aimed at motivating these people to perform the actions.

Step 4. Working out the contours of engagement and progress. A motivated participant of the process performs an action and receives a feedback (in the form of tangible or intangible rewards).

Step 5. Description of the elements of getting a pleasure. The desire to have pleasure is one of the strongest motives that induce a person to do something with the enthusiasm. Therefore, using the game mechanism, game elements and forming game thinking, it is possible to achieve employee involvement, as well as to form new experience and new ways of solving problems [13].

Step 6. Choosing gamification building tools. At the final stage of introducing the gamification elements into management practice, a platform shall be selected on which the tasks will be implemented. A system of mechanics is being thought out, that is, specific tasks, a mechanism for cooperation, accumulation of resources, a reward system.

The introduction of the considered management model into the practice of managing a university makes it possible to implement the principle of academic freedom, which is a key factor in ensuring the sustainability of education development. Universities manage their activities as fully as the state allowed them to do so. However, there is a system of restraining the management process and certain counterbalances that are implemented in two directions:

1) at the state level, monitoring and evaluating the activities of the university;

2) at the university level (internal assessment of the quality of the educational activities).

At the same time, the directions complement each other, since the results of monitoring and evaluation at the state level depend on the organization of the internal assessment of the quality of the educational activities.

According to Art. 93 of the Law "On Education in the Russian Federation", state control (supervision) includes federal state control of the quality of education and federal state supervision in the field of education, carried out by authorized federal executive bodies and executive bodies of the constituent entities of the Russian Federation.

In accordance with the order of Rosobrnadzor dated December 22, 2014 No. 1934, the following types of examinations in the field of education were approved [14]:

1. Expertise in the implementation of federal state supervision in the field of education.

2. Expertise in the implementation of federal state control of the quality of education.

3. Expertise in the implementation of the license control.

4. Expertise in the implementation of state supervision over compliance with the legislation of the Russian Federation on the protection of children from information used in the educational process that is harmful to their health and (or) development.

Analyzing the data presented on the website of the Federal Service for Supervision in Education [15] for the period from 2018 to 2019, the control and supervisory authorities revealed about 1000 violations (Table 5). 
Table 5. Violations identified in the course of monitoring and supervisory activities

\begin{tabular}{|c|c|c|c|c|}
\hline \multirow[t]{2}{*}{ Scope of monitoring and supervisory activities } & \multicolumn{2}{|c|}{$\begin{array}{l}\text { Number of } \\
\text { violations }\end{array}$} & \multicolumn{2}{|c|}{$\begin{array}{c}\text { Structure of } \\
\text { violations by } \\
\text { types of the } \\
\text { monitoring } \\
\text { measures, } \%\end{array}$} \\
\hline & 2018 & 2019 & 2018 & 2019 \\
\hline Federal state supervision in the field of education & 204 & 182 & 38.0 & 28.9 \\
\hline Federal state monitoring of education quality & 50 & 120 & 9.3 & 19.1 \\
\hline Licensing monitoring in the field of education & 283 & 310 & 52.7 & 49.3 \\
\hline $\begin{array}{l}\text { State supervision over the observance of the legislation } \\
\text { of the Russian Federation on the protection of children } \\
\text { from information harmful to their health and (or) } \\
\text { development by educational organizations, as well as to } \\
\text { information products used in the educational process }\end{array}$ & $-*$ & 17 & - & 2.7 \\
\hline Total & 537 & 629 & 100.0 & 100.0 \\
\hline
\end{tabular}

*The facts of violations in the state supervision over the observance of the legislation of the Russian Federation by educational organizations on the protection of children from information harmful to their health and (or) development, to the information products used in the educational process, have been recorded only since 2019 .

Any types of state control (supervision) are carried out through the inspections of the relevant organizations. Most of the violations are related to licensing control in the field of education and state supervision. Naturally, the fulfillment of all the requirements in full compliance with the legislation is utopian for any educational organization, but it is possible to ensure the fulfillment of the minimum requirements. Within the framework of the article, we will consider the fulfillment of several requirements related to the Federal State Control of the Quality of Education. One of the most common violations mentioned in the reporting data in the implementation of state control is non-compliance with the requirements for educational and methodological support.

Educational and methodological support is understood as a set of educational and methodological materials that contribute to the achievement of the planned results of mastering the educational program of higher education by the students. The obligation to form educational and methodological support of the courses is supported at the legislative level (Fig. 2).

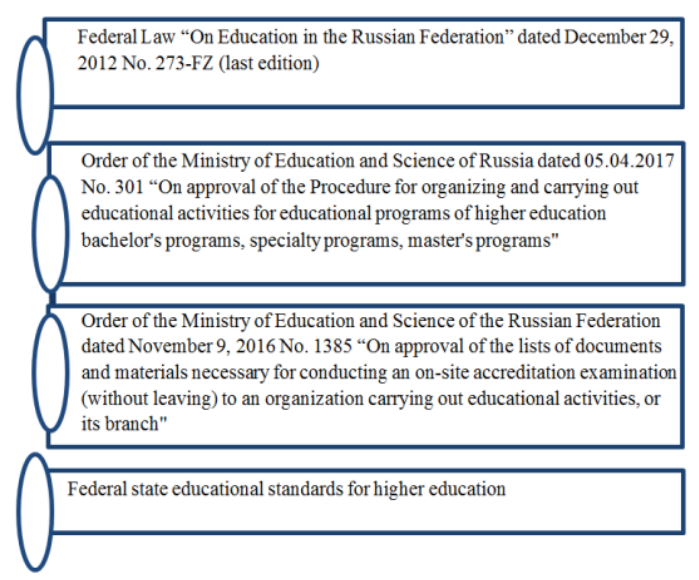

Fig. 2. The main regulatory legal acts that determine the need for educational and methodological support of the educational process 
The most substantive requirements for educational and methodological support are reflected in the Federal State Educational Standards of Higher Education. Educational and methodological support is part of the digital information and educational environment (DIEE) of the university (Table 6).

Table 6. FSES requirements for educational and methodological support of the educational process

\begin{tabular}{|c|c|c|}
\hline Item FGOS3++ & $\begin{array}{l}\text { What confirms the fulfillment of the } \\
\text { paragraph? }\end{array}$ & How to check? \\
\hline $\begin{array}{l}\text { cl. } 4.2 .2 \text { Access to curricula, } \\
\text { work programs of the courses } \\
\text { (modules), practices, } \\
\text { publications of digital library } \\
\text { systems and electronic } \\
\text { educational resources specified } \\
\text { in the working programs }\end{array}$ & $\begin{array}{l}\text { 1. Curriculum } \\
\text { 2. Working programs of the courses, } \\
\text { internship } \\
\text { 3. Documents confirming the existence (or } \\
\text { the right to use) digital (electronic) libraries } \\
\text { that provide access to the professional } \\
\text { databases, information reference and search } \\
\text { systems, as well as other information } \\
\text { resources } \\
\text { 4. Documents and materials confirming the } \\
\text { presence (or the right to use) the } \\
\text { organization's DIEE } \\
\text { 5. Agreements with EBS } \\
\text { 6. Log of registration of logins and } \\
\text { passwords issued to the students } \\
\text { 7. LNA regulating the functioning of the } \\
\text { DIEE }\end{array}$ & $\begin{array}{l}\text { Establishing in documents } \\
\text { and materials, as well as } \\
\text { when working in DIEE, } \\
\text { the conformity of the } \\
\text { functioning and filling of } \\
\text { DIEE with the } \\
\text { requirements of the } \\
\text { Federal State Educational } \\
\text { Standard of Higher } \\
\text { Education }\end{array}$ \\
\hline $\begin{array}{l}\text { cl. } 4.3 .2 \text { The organization must } \\
\text { be provided with the necessary } \\
\text { set of licensed and free } \\
\text { software, including that of } \\
\text { domestic production (the } \\
\text { composition is determined in } \\
\text { the work programs of the } \\
\text { courses (modules) and is } \\
\text { subject to updating, if } \\
\text { necessary) }\end{array}$ & $\begin{array}{l}\text { 1. Curriculum } \\
\text { 2. Working programs of the courses, } \\
\text { internship } \\
\text { 3. Software license } \\
\text { 4. Contracts for software ownership } \\
\text { 5. Certificate on the material and technical } \\
\text { support of the educational program } \\
\text { 6. Syllabus. }\end{array}$ & $\begin{array}{l}\text { Establishing the presence } \\
\text { in OO of a set of licensed } \\
\text { software that meets the } \\
\text { requirements of the } \\
\text { Federal State Educational } \\
\text { Standard of Higher } \\
\text { Education in the } \\
\text { documents and materials }\end{array}$ \\
\hline $\begin{array}{l}\text { p. 4.3.3 When using printed } \\
\text { publications in the educational } \\
\text { process, the library fund must } \\
\text { be equipped with printed } \\
\text { publications at the rate of at } \\
\text { least } 0.25 \text { copies of each of the } \\
\text { publications specified in the } \\
\text { working programs of the } \\
\text { courses (modules), internship } \\
\text { programs, per student from } \\
\text { among the persons, } \\
\text { simultaneously mastering the } \\
\text { relevant courses (module), } \\
\text { passing the relevant internship }\end{array}$ & $\begin{array}{l}\text { 1. Curriculum } \\
\text { 2. Working programs of the courses, } \\
\text { internship } \\
\text { 3. Agreements with EBS } \\
\text { 4. Contingent information (ВПО-1) }\end{array}$ & $\begin{array}{l}\text { Establishment of the } \\
\text { presence of printed } \\
\text { publications in accordance } \\
\text { with the standard specified } \\
\text { in the Federal State } \\
\text { Educational Standard of } \\
\text { Higher Education in the } \\
\text { documents and materials }\end{array}$ \\
\hline $\begin{array}{l}\text { cl. } 4.3 .4 \text { Students should be } \\
\text { provided with the access } \\
\text { (remote access), including in } \\
\text { the case of using e-learning, } \\
\text { remote learning technologies, } \\
\text { to modern professional } \\
\text { databases and information } \\
\text { reference systems, the } \\
\text { composition of which is } \\
\text { determined in the working } \\
\text { programs of the courses } \\
\text { (modules) and is subject to } \\
\text { update (if necessary) }\end{array}$ & $\begin{array}{l}\text { 1. Curriculum } \\
\text { 2. Working programs of the courses, } \\
\text { internship } \\
\text { 3. Documents confirming the existence and } \\
\text { the right to use the digital (electronic) } \\
\text { libraries that provide access to the } \\
\text { professional databases, information } \\
\text { reference and search systems, as well as } \\
\text { other information resources }\end{array}$ & $\begin{array}{l}\text { Establishment of } \\
\text { documents and materials, } \\
\text { as well as when working } \\
\text { on the Internet, providing } \\
\text { access (remote access) to } \\
\text { modern professional } \\
\text { databases and information } \\
\text { reference systems that } \\
\text { meet the requirements of } \\
\text { the Federal State } \\
\text { Educational Standard of } \\
\text { Higher Education }\end{array}$ \\
\hline
\end{tabular}


The fulfillment of the above requirements is in one way or another connected with the fulfillment of the main functional duties of the academic staff, since the compliance with the requirements is confirmed by the data specified in the working programs of the courses, internship. A modern academic worker must accordingly have new professional functions that allow him to work in a digital information and educational environment. According to M.N. Andryukhina, against the background of the need to integrate three professional functions in pedagogical activity: teacher, didactic and engineer, perhaps one should think not about combining three roles in the person of one teacher, but about introducing a new specialty in the field of education - digital engineering teacher. Having such a specialist and a didactic teacher in a team will remove from the latter part of the unreasonable functional load associated with the fulfillment of the requirements imposed by the legislation [16].

The educational organization must create conditions to ensure the fulfillment of the set requirements and monitor the implementation thereof.

To meet the requirements of the regulatory documents in terms of the educational and methodological support, the authors have developed a multifunctional management system that allows, on the one hand, to provide the ability to view the documentation, taking into account a horizontal interdependence, based on the requirements of the Federal State Educational Standard of Higher Education, on the other hand, the ability to build a vertical document with a cumulative effect.

The work of the academic staff (AS) in DIEE in terms of the above requirements is built according to an algorithm that allows collecting, storing, processing, updating information, reproducing (Fig. 3).

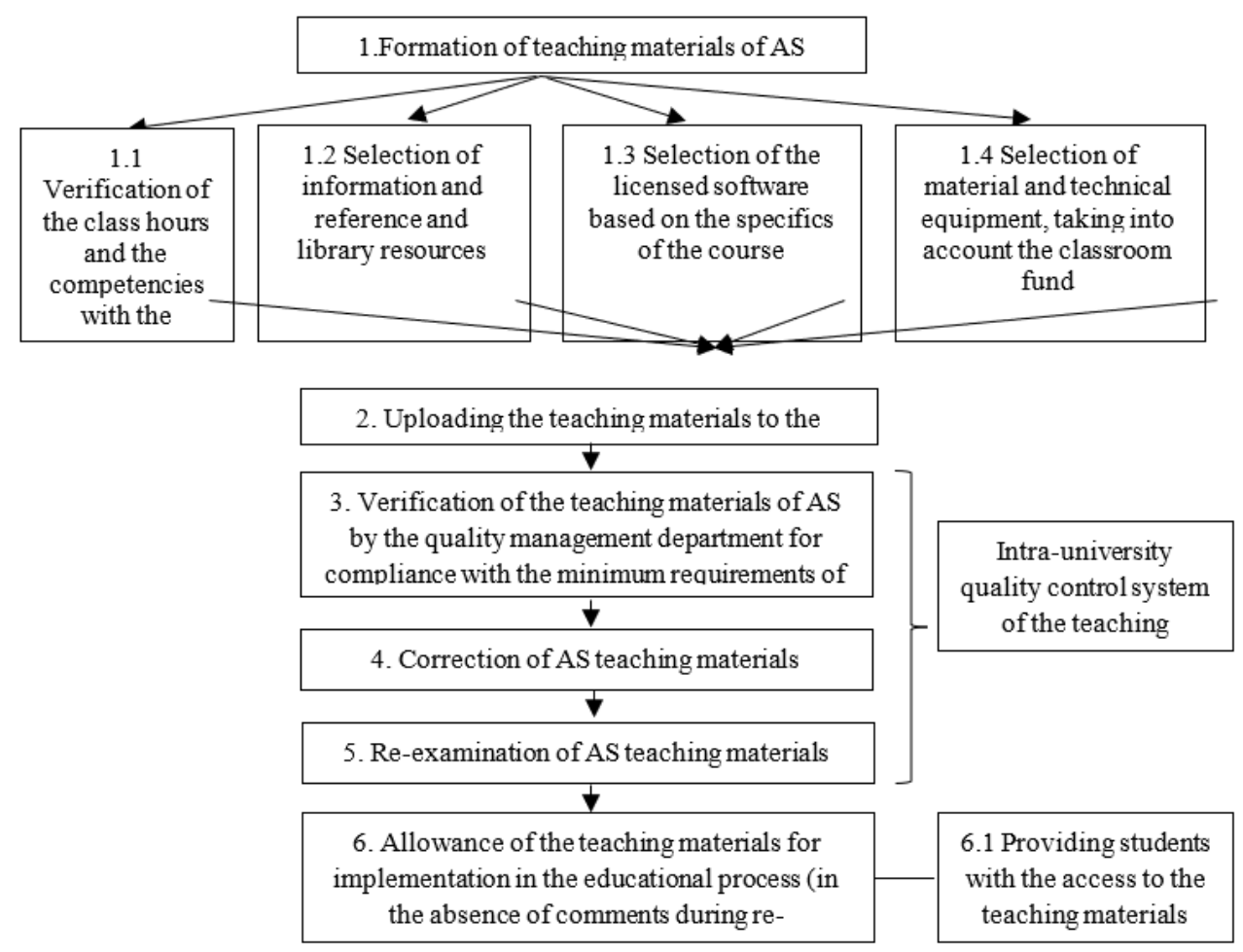

Fig. 3. Algorithm for the formation of the educational-methodical complex of the courses

The teaching materials of the course of the main educational program in the specialty (direction of training) is formed in DIEE of the university and is located in the personal 
account of the academic staff. The information available in the personal account has the form of a table reflecting the list of courses assigned to the AS. The consolidation of one or another course for the AS is carried out by the head of the department based on the distribution of the academic load (Fig. 4).

\begin{tabular}{|c|c|c|c|c|c|c|c|c|c|c|c|c|}
\hline \multirow[b]{2}{*}{$\begin{array}{l}\text { Inde } \\
\mathrm{x}\end{array}$} & \multirow[b]{2}{*}{$\begin{array}{l}\text { Cour } \\
\text { se }\end{array}$} & \multirow[b]{2}{*}{$\begin{array}{c}\text { Departm } \\
\text { ent }\end{array}$} & \multirow[b]{2}{*}{$\begin{array}{c}\text { Abstr } \\
\text { act }\end{array}$} & \multirow[b]{2}{*}{$\begin{array}{l}\text { Pח } \\
\text { Д }\end{array}$} & \multirow[b]{2}{*}{$\begin{array}{c}\Phi O \\
\mathrm{C}\end{array}$} & \multicolumn{6}{|c|}{ Teaching and learning aids } & \multirow[b]{2}{*}{$\begin{array}{c}\text { Monitor } \\
\text { ing }\end{array}$} \\
\hline & & & & & & $\begin{array}{l}\text { Lectu } \\
\text { re } \\
\text { cours } \\
\text { e }\end{array}$ & $\begin{array}{c}\text { by } \\
\text { practi } \\
\text { cal } \\
\text { classe } \\
\text { s }\end{array}$ & $\begin{array}{c}\text { by } \\
\text { laborat } \\
\text { ory } \\
\text { work }\end{array}$ & $\begin{array}{c}\text { by } \\
\text { students' } \\
\text { self } \\
\text { develop. } \\
\text { ment } \\
\text { work }\end{array}$ & $\begin{array}{c}\text { by } \\
\text { implementa } \\
\text { tion of Kח } \\
\text { (KP) }\end{array}$ & $\begin{array}{c}\text { by } \\
\text { examinati } \\
\text { ons }\end{array}$ & \\
\hline $\begin{array}{c}\text { Б1.0 } \\
.1\end{array}$ & $\begin{array}{l}\text { Cour } \\
\text { se } 1 \\
\text { nam } \\
\text { e } \\
\end{array}$ & $\begin{array}{l}\text { Develop } \\
\text { ing } \\
\text { departm } \\
\text { ent } \\
\end{array}$ & + & + & + & + & + & $\underline{n / a}$ & + & $\underline{\mathrm{n} / \mathrm{a}}$ & + & $\otimes$ \\
\hline $\begin{array}{c}\text { b1.o } \\
.2\end{array}$ & $\begin{array}{c}\text { Cour } \\
\text { se } 2 \\
\text { nam } \\
\text { e } \\
\end{array}$ & $\begin{array}{c}\text { Develop } \\
\text { ing } \\
\text { departm } \\
\text { ent } \\
\end{array}$ & - & - & - & - & - & $\underline{\mathrm{n} / \mathrm{a}}$ & - & $\underline{\mathrm{n} / \mathrm{a}}$ & - & $\square$ \\
\hline \multicolumn{3}{|c|}{ Requires } & & & & & & & & & & \\
\hline \multirow{2}{*}{\multicolumn{3}{|c|}{ Total developed }} & $\frac{2}{1}$ & $\frac{2}{1}$ & $\frac{2}{1}$ & $\frac{2}{1}$ & $\frac{2}{1}$ & 0 & $\frac{2}{1}$ & $\begin{array}{l}0 \\
0\end{array}$ & $\frac{2}{1}$ & \\
\hline & & & 50 & 50 & 50 & 50 & 50 & 100 & 50 & 100 & 50 & \\
\hline
\end{tabular}

Fig. 4. Option for presenting educational and methodological complexes in the personal account of the academic staff

In his personal account, the AS can see a list of all courses and materials to work with. To fill in the teaching materials, the AS selects the appropriate cell and loads his material. After loading the material, a "+" sign appears in the cell.

The uploaded material is subject to an intra-university quality control system, which is carried out by the specialists of the quality management department and persons appointed in charge of the department for an appropriate control.

The result of the control is the receipt of a mark on the approval of the teaching materials and an allowance for implementation in the educational activities of the organization, after which the corresponding line for the course is highlighted in "green", which limits the introduction of the adjustments to this material.

The presented model for the development and control of the teaching materials allows you to implement the entire process in the gamification mode in steps (Fig. 5).

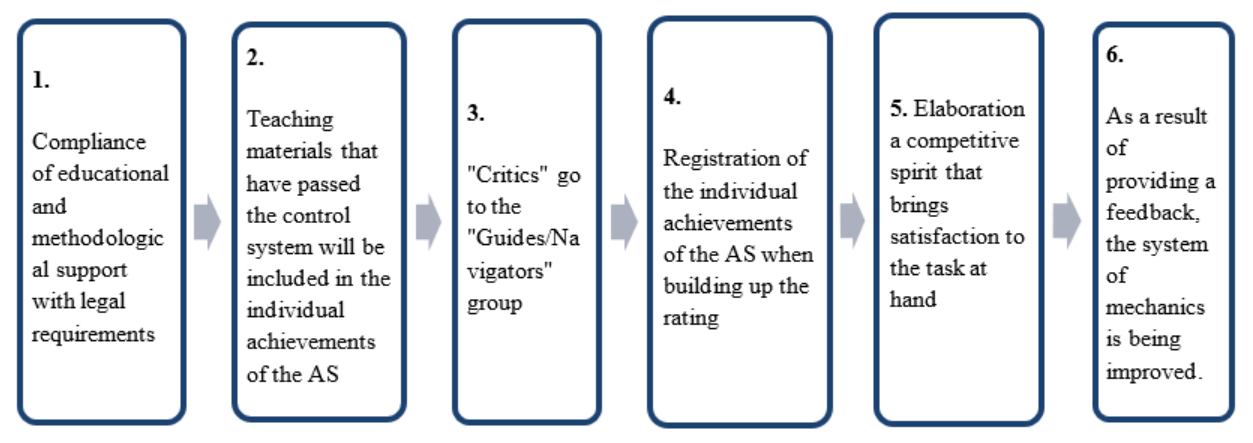

Fig. 5. Option for presenting educational and methodological complexes in the personal account of the academic staff

The present algorithm is applicable to all the processes that require documentary confirmation and support in the framework of compliance with the legislation in the field of education. 


\section{Conclusions}

A necessary condition for the effective use of the technological and human resources in the management of a university is their adaptation to the existing tasks set for the higher education. Using the presented mechanics in management processes will allow achieving the following results:

1) will improve the quality of the developed teaching materials by stimulating the interest of the AS to perform the tasks related to their development and updating. In this case, we can say that the game model, when fulfilling the assigned tasks, stimulates rival relations in the team in terms of developing the correct teaching materials complex that meets the requirements of the legislation in the field of education. In addition, the presented mechanics will increase the objectivity, transparency and reliability of information exchange both between the AS and the management of the university, as well as between the AS and the students;

2) measure the indicators of individual effectiveness of both an individual employee and the department as a whole;

3) create a unified information base that provides documentary evidence of compliance with the minimum requirements of the legislation in the field of education;

4) increase the level of digitalization in the educational organization and reduce the time, and in some cases, exclude the implementation of certain tasks;

5) identify and systematize the problems associated with the implementation of certain tasks, which will allow finding ways to solve them in advance, thereby eliminating their negative impact on the processes in the university and will contribute to the development of a sustainable educational environment.

\section{Acknowledgements}

The paper was prepared within the framework of a grant from the Trans-Baikal Institute of Railway Transport - a branch of the Federal State Budgetary Educational Institution of Higher Education - Irkutsk University of Railways - on the issue of "Development of a system for monitoring the compliance with legislative requirements in the field of education."

\section{References}

1. Creation of entrepreneurial universities: organizational directions of transformation, $\mathbf{1 1}$ (2019)

2. A.A. Mamedov, Bulletin of RUDN University, series of Legal Sciences, 2, 29 (2011)

3. A.K. Klyuev, O.B. Tomilin, I.M. Fadeeva, O.O. Tomilin, University management: results of transformation, University management: practice and analysis, 22(1), 94 (2018)

4. D. Newstrom, Organizational behavior (2000)

5. K. Blanchard, P. Zigarmi, D. Zigarmi, One minute manager and situational leadership, $56(2018)$

6. Blanchard K. Leadership. To the heights of the success. The way to building a highly effective organization, 62 (2011)

7. Participation in the management of the university: Scientific publication, 8 (2016)

8. Kevin Werbach, Dan Hunter Engage and Conquer. Game thinking in the service of business, 35 (2015) 
9. V.V. Artamonova, Historical and social-educational thought, 10(2/2), 38 (2018)

10. Kevin Werbach, Dan Hunter Engage and Conquer. Game thinking in the service of business, 126 (2015)

11. Eyal Nir, On the hook. How to create habit forming products, 80 (2017)

12. David A. O'Brien, The Navigator's Handbook: 101 Leadership Lessons for Work and Life (2017)

13. V.V. Artamonova, Historical and social-educational thought, 10(2/2), 40 (2018)

14. Order of the Federal Service for Supervision in Education and Science, dated December 22, 2014 No.1934 "On approval of the List of types of examinations, for which the involvement of experts is required"

15. Official site of the Federal Service for Supervision in Higher Education and Science, http://www.obrnadzor.gov.ru/ru/

16. L.M. Andryukhina, N.O. Sadovnikova, S.N. Utkina, The Education and Science Journal, 22(3), 136 (2020) 